\title{
Sexual Morphometric Variation in Pronotum of Dorcadion anatolicum Pic, 1900 (Cerambycidae:Coleoptera)
}

\author{
Aslı DOĞAN SARIKAYA* Atılay Yağmur OKUTANER \\ Kirşehir Ahi Evran University, Faculty of Art and Science, Department of Anthropology, Kirşehir, Turkey.
}

How to cite: Doğan Sarikaya, A. \& Okutaner, A.Y. (2021). Sexual Morphometric Variation in Pronotum of Dorcadion anatolicum Pic, 1900 (Cerambycidae:Coleoptera). J. Anatolian Env. and Anim. Sciences, 6(1), 84-87.

Atıf yapmak için: Doğan Sarikaya, A. \& Okutaner, A.Y. (2021). Dorcadion anatolicum Pic, 1900 (Cerambycidae: Coleoptera) Pronotumunda Eşeysel Morfometrik Varyasyon. Anadolu Çev. ve Hay. Dergisi, 6(1), 84-87.

D: https://orcid.org/0000-0002-8739-0122 (iD): https://orcid.org/0000-0001-6585-1824

*Corresponding author's: Aslı DOGAN SARIKAYA

Kırșehir Ahi Evran University, Faculty of Art and Science, Department of Anthropology, Kırşehir, Turkey.

凶: aslidgn@gmail.com

\begin{abstract}
Understanding sexual dimorphism is very important in studies of insect evolution. Though sexual dimorphism has been the subject of numerous entomological studies there has no examined sexual dimorphism related to Dorcadion anatolicum Pic, 1900 which is endemic to Turkey. In this study, using geometric morphometrics, we analyzed the sexual size and shape dimorphism of pronotum of Dorcadion anatolicum Pic, 1900. Samples of the Dorcadion anatolicum were collected from Konya Province, Turkey (Taşkent District, Avşar Town, Feslekan Plateau, 36 51'9" N, 32 30'44" E) on March-April 2018. Sexes of samples were distinguished by the shape and size of the fore tarsus and confirm by using gonads. A total of 69 specimens ( 32 females and 37 males) were used in this study. The independent samples t-test showed that the centroid size mean of males is significantly different from that of the females, for pronotum $(t=7.129, \mathrm{df}=67, \mathrm{p}=0.000)$. Statistically significant differences were found between sexes by discriminant function analysis. Our results of geometric morphometrics revealed that the size and shape of the pronotum can be effectively used in morphological discrimination of the sexes.
\end{abstract}

Keywords: Coleoptera, Dorcadion anatolicum, geometric morphometrics, pronotum, sexual dimorphism.

\section{Dorcadion anatolicum Pic, 1900 (Cerambycidae: Coleoptera) Pronotumunda Eşeysel Morfometrik Varyasyon}

*Sorumlu yazar:

Aslı DOĞAN SARIKAYA

Kırşehir Ahi Evran Üniversitesi, Fen

Edebiyat Fakültesi, Antropoloji Bölümü,

Kırșehir, Türkiye.

凶: aslidgn@gmail.com
Öz: Eşeysel dimorfizmi anlamak böcek evrimi çalışmalarında oldukça önemlidir. Eşeysel dimorfizm çalışmaları birçok entomolojik çalışmaya konu olmasına rağmen, Türkiye'ye endemik bir tür olan Dorcadion anatolicum Pic, 1900 ile ilgili bu konuda bir çalışma bulunmamaktadır. Bu çalışmada, geometrik morfometri kullanarak Dorcadion anatolicum Pic, 1900 pronotumunun eşeysel boyut ve şekil dimorfizmi analiz edilmiştir. Dorcadion anatolicum örnekleri Mart-Nisan $2018^{\prime}$ de Konya ilinden (Taşkent İlçesi, Avşar Kasabası, Feslekan Yaylası, 3651'9” N, 32³0'44" D) toplanmıştır. Örneklerin eşeyleri ön tarsusun şekli ve boyutuna göre ayırt edildi ve gonadlar kullanılarak doğrulandı. Bu çalışmada toplam 69 örnek (32 dişi ve 37 erkek) kullanılmıştır. Bağımsız örneklem t-testi, erkeklerin centroid size ortalamasının pronotum için dişilerden önemli ölçüde farklı olduğunu gösterdi $(t=7.129, \mathrm{df}=67, \mathrm{p}=0.000)$. Ayırt edici fonksiyon analiz ile eşeyler arasında istatistiksel olarak anlamlı farklılıklar bulundu. Geometrik morfometri sonuçlarımız, pronotumun boyutunun ve şeklinin cinsiyetlerin morfolojik ayrımında etkili bir şekilde kullanılabileceğini ortaya koydu.

Anahtar kelimeler: Coleoptera, Dorcadion anatolicum, esseysel dimorfizm, geometrik morfometri, pronotum. 


\section{INTRODUCTION}

Differences between sexes in morphological characters are the fact in many animal taxa; the most visible one is body size (Gannon \& Rácz, 2006). Nearly all animal species are sexually size dimorphic (Andersson, 1994; Fairbairn, 2013). The aspect of the sexual difference (whether males or females are larger) is different among groups (Koehl, 1996; Wainwright, 1994). Males generally being larger than females in mammals and birds whereas in insects females tend to be larger than males, which gives them adaptive advantages such as greater fecundity and better parental care (Andersson, 1994; Forrest, 1987; Moller \& Zamora-Muñoz, 1997). In the last few years, the revolution of geometric morphometrics has encouraged for researcher the way to analyze the phenotype particularly for morphologically (Eldred et al., 2016; Pretorius \& Scholtz, 2001; Sukhodolskaya \& Saveliev, 2017; Young, 2015). This technique has been especially helpful to quantify the differences in both size and shape between sexes of a Coleoptera species as display in many studies (Benítez, 2013; Benítez et al., 2013; Lemic et al., 2014; Lemic et al., 2016; Mikac et al., 2016; Nair et al., 2019; Vesovic et al., 2019).

For especially Arthropoda (or insects), Turkey is an important biogeographical area with its geographical location, climatic zones, various topography, and remarkable biodiversity. Turkey is also crucial land for Dorcadionini that has a Palaearctic (North Africa and Western Europe to China) chorotype (Danilevsky, 2019). Recently, the Dorcadionini fauna of Turkey was reviewed, and a list of 278 species-group taxa was given by in Özdikmen (2016). Dorcadion anatolicum Pic, 1900 (Coleoptera: Cerambycidae) is endemic to Central and Southeastern Anatolian Regions of Turkey (Özdikmen, 2010).

The morphological variations of Dorcadion are useful for systematic and evolutionary studies both interspecies and intraspecies (Dascălu \& Fusu, 2012; Doğan Sarıkaya et al., 2019). Although there is a noticeable dimorphism in total size between the sexes in species of the Dorcadion, there is almost no study on how much this difference reflects on the shape variation. Also, there are no known studies on the description of sexual dimorphism on Dorcadion anatolicum using geometric morphometrics. The main purpose of this study was to apply geometric morphometrics to describe sexual dimorphism in the pronotum of Dorcadion anatolicum Pic, 1900 (Coleoptera: Cerambycidae).

\section{MATERIAL AND METHOD}

Samples of the Dorcadion anatolicum were collected from Konya Province, Turkey (Taşkent District,
Avşar Town, Feslekan Plateau, 36 51'9” N, 32³0'44” E) on March-April 2018.

Sexes of samples were distinguished by the shape and size of the fore tarsus and confirm by using gonads. A total of 69 specimens ( 32 females and 37 males) were used in this study. A single image was taken by a camera attached to Leica EZ4HD microscope for each specimen of pronotum. Landmark-based morphometric methods were chosen as they are the most effective technique in learning about the shape information of an organism and eligibility to use powerful statistical methods for testing differences in shape. In this study, 10 landmarks on the pronotum were digitized on photographs using tpsDig 2.17 (Rohlf, 2013). The position of landmarks is given in Figure 1.

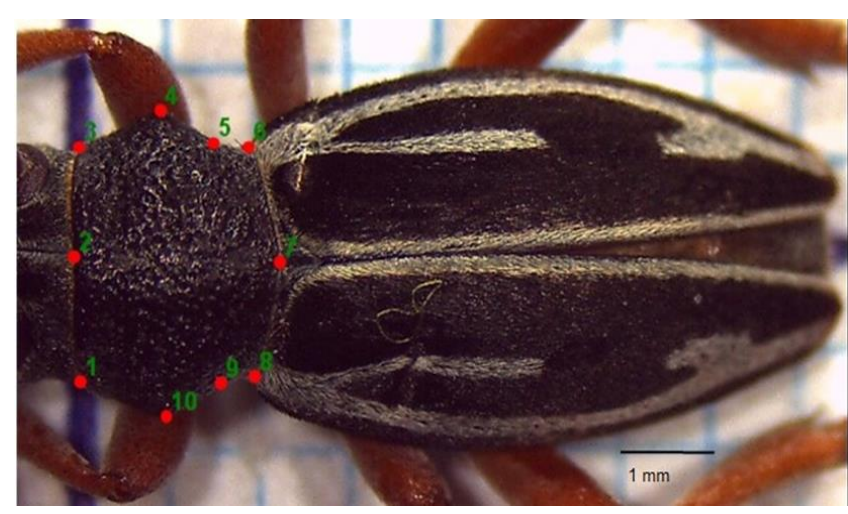

Figure 1. Selected landmarks on Dorcadion anatolicum male, representing the dorsal side of the pronotum: 1) Anterior margin left edge; 2) middle of anterior margin; 3) anterior margin right edge; 4) right spine apex; 5) right protuberance posterior limit; 6) posterior right edge; 7) middle of posterior margin; 8) posterior margin left edge; 9) left protuberance posterior limit; and 10) left spine apex.

Statistical Analysis: To compare pronotum size between sexes, the centroid size (CS) (square root of the sum of the square distances between each landmark and the centroid) (Bookstein, 1986) was computed. The independent samples t-test was performed using the IBM SPSS 25. A generalized procrustes analysis (GPA) has been developed to superimposition of landmark configurations and to eliminate the effects of translation, rotation and scale (Rohlf, 1999). The software package MorphoJ (Klingenberg, 2011) was used to perform the GPA, principle component analysis (PCA) and finally discriminant function analysis (DFA) with leave-one-out cross validation.

\section{RESULTS AND DISCUSSION}

The independent samples t-test showed that the CS mean of males is significantly different from that of the females, for pronotum. $(\mathrm{t}=7.129, \mathrm{df}=67, \mathrm{p}=0.000)$. Figure 2 shows box-plot of CS for pronotum. Further, distributions of females appear to be more variable with 
respect to CS than males. Females are larger than males for pronotum

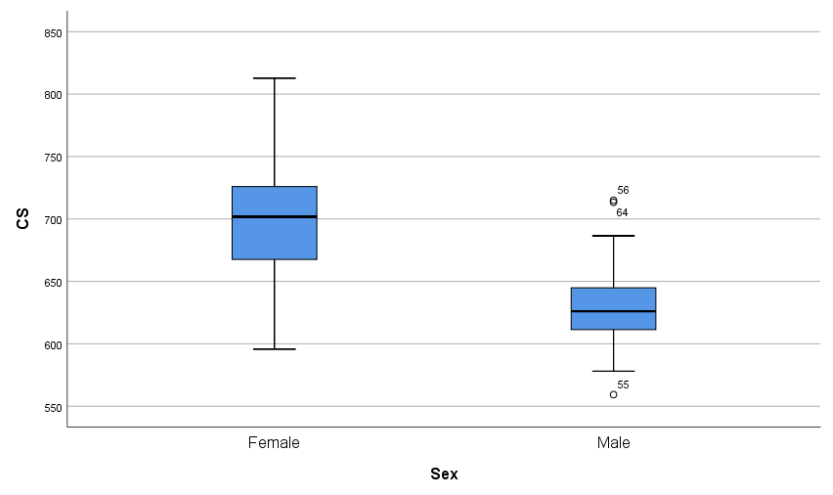

Figure 2. Box-plot of centroid size for pronotum for both sexes.

PCA of all individuals explained $66.6 \%$ of shape variation within samples by the first two principle components (PC) extracted from the variance-covariance matrix (PC1 explains 54.2\% and PC2, 12.4\%). A total of up to seven axes were required to cover more than $90 \%$ of the shape variation. In the PCA plots, individuals of the two sexes were clearly distinct in two cluster by PC1 (Figure 3).

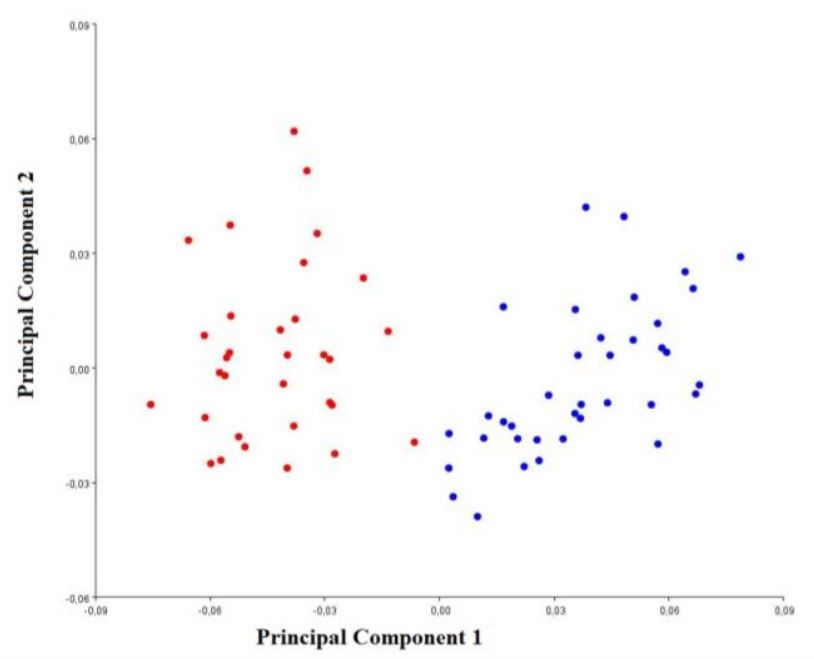

Figure 3. Shape differences between sexes, female (red) and male (blue).

DFA was performed using the procrustes coordinates to determine the degree of morphological separation between sexes. The DFA found significant differences between means in procrustes distances $(\mathrm{P}<$ 0.0001) for the two sexes. Leave-one-out cross validation of DFA conducted on the procrustes coordinates of pronotum evidenced that $96.9 \%$ of female group and $97.3 \%$ of male group were correctly classified (Figure 4).

Also, the results of DFA show that all the landmarks with the greatest variation indicating that females have a wider and shorter pronotum than males. This is also related to elongated and sharpened from both anterior and posterior parts of the pronotum shape in male
(Figure 4). Although there are many studies significant differences in pronotum shape in Coleoptera (Eldred et al., 2016; Li et al., 2016; Ober \& Connolly, 2015; Pizzo et al., 2006), geometric morphometrics was applied here for sexual dimorphism to Dorcadion for the first time. Our study found significant sexual dimorphism on pronotum in female and male of Dorcadion anatolicum.

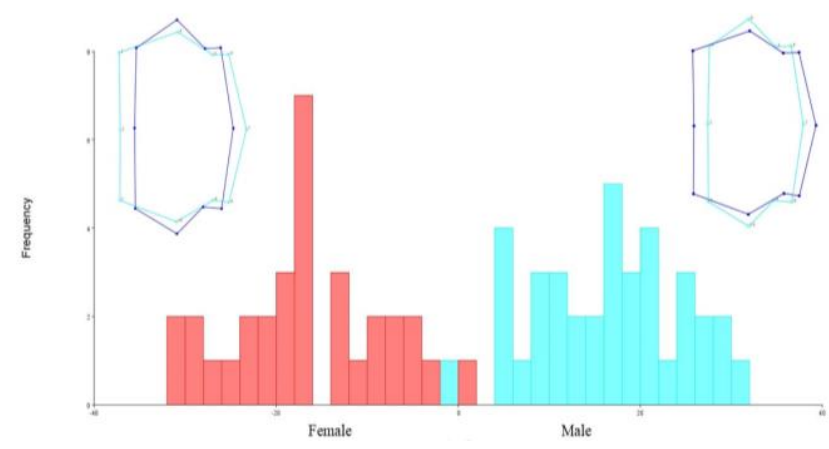

Figure 4. Leave-one-out cross validation scores of shape variables of pronotum. Wire-frame graphs were shown for female and male respectively at the top of left and right of each figure. The extreme changes of shape in positive and negative direction was shown by the violet lines and mean shape of pronotum was shown by blue lines. The scale for figure is ( -20 to 20$)$.

\section{CONCLUSION}

As a result, sexual dimorphism was highly significant in the present study. The fact that the pronotum shows such a high degree of sexual difference emphasizes the importance of intra specific shape variation. Extending this preliminary study with different body parts (head, elytra etc.) and different locality samples will give us to understand of the process in which sexual dimorphism is affected.

\section{ACKNOWLEDGEMENTS}

This study was supported by Ahi Evran University, Scientific Research Unit, Kırşehir, Turkey, Grant Project No: FEF.A4.18.

\section{CONFLICT OF INTEREST STATEMENT}

The authors declare that there are no conflicts of interest.

\section{REFERENCES}

Andersson, M. (1994). Sexual selection. Princeton: Princeton University Press, USA, 247-297p.

Benítez, H.A., Sanzana, M.J., Jerez, V., Parra, L.E., Hernandez, C.E. \& Canales-Aguirre, C.B. (2013). Sexual shape and size dimorphism in carabid beetles of the genus Ceroglossus: is 
geometric body size similar between sexes due to sex ratio? Zoological Science, 30, 289-295.

Benítez, H.A. (2013). Sexual dimorphism using geometric morphometric approach. In: Moriyama H (Ed.) Sexual Dimorphism. IntechOpen, London, 35$50 \mathrm{p}$.

Bookstein, F.L. (1986). Size and shape spaces for landmark data in two dimensions. Statistical Science, 2, 181-222.

Danilevsky, M.L. (2019). Catalogue of Palaearctic Cerambycoidea.

(http://www.cerambycidae.net/catalog.pdf) April 2019).

Eldred, T., Meloro, C., Scholtz, C., Murphy, D., Fincken, K. \& Hayward, M. (2016). Does size matter for horny beetles? A geometric morphometric analysis of interspecific and intersexual size and shape variation in Colophon haughtoni Barnard, 1929, and C. kawaii Mizukami, 1997 (Coleoptera: Lucanidae). Organisms Diversity \& Evolution, 16(4), 821833.

Fairbairn, D.J. (2013). Odd couples: Extraordinary differences between the sexes in the animal kingdom, Princeton University Press. USA, 1-9p.

Forrest, T.G. (1987). Insect size tactics and developmental strategies. Oecologia, 73(2), 178184.

Gannon, W.L. \& Rácz, G.R. (2006). Character displacement and ecomorphological analysis of two long-eared Myotis (M. auriculus and $M$. evotis). Journal of Mammalogy, 87(1), 171-179.

Klingenberg, C.P. (2011). MorphoJ: an integrated software package for geometric morphometrics. Molecular Ecology Resources, 11(2), 353-357.

Koehl, M. (1996). When does morphology matter? Annual Review of Ecology and Systematics, 27, 501-542.

Lemic, D., Benítez, H.A. \& Bazok, R. (2014). Intercontinental effect on sexual shape dimorphism and allometric relationships in the beetle pest Diabrotica virgifera virgifera LeConte (Coleoptera: Chrysomelidae). Zoologischer Anzeiger - A Journal of Comparative Zoology, 253(3), 203-206. DOI: 10.1016/j.jcz.2014.01.001

Lemic, D., Benítez, H.A., Püschel, T.A., Gasparic, H.V., Satvar, M. \& Bazok, R. (2016). Ecological morphology of the sugar beet weevil Croatian populations: Evaluating the role of environmental conditions on body shape. Zoologischer Anzeiger - A Journal of Comparative Zoology, 260, 25-32.

Li, S., Ricchiardi, E., Bai, E. M. \& Yang, X. (2016). A taxonomy review of Oreoderus Burmeister, 1842 from China with a geometric morphometric evaluation (Coleoptera: Scarabaeidae). Zookeys, 13(552), 67-89.

Mikac, K.M., Lemic, D., Bazok, R. \& Benítez, H.A. (2016). Wing shape changes: a morphological view of the Diabrotica virgifera virgifera European invasion. Biological Invasions, 18, 3401-3407.
Moller, A.P. \& Zamora-Muñoz, C. (1997). Antennal asymmetry and sexual selection in a cerambycid beetle. Animal Behaviour, 54, 1509-1515.

Nair, P., Hunter, A.H., Worsham, M.L., Stehle, M., Gibson, J.R. \& Nowlin, W.H. (2019). Sexual dimorphism in three species of Heterelmis Sharp (Coleoptera: Elmidae). The Coleopterists Bulletin, 73, 1075-1083. DOI: 10.1649/0010065X-73.4.1075

Ober, K.A. \& Connolly, T.C. (2015). Geometric morphometric and phylogenetic analyses of Arizona Sky Island populations of Scaphinotus petersi Roeschke (Coleoptera: Carabidae). Zoological Journal of the Linnean Society, 175, 107-118.

Özdikmen, H. (2010). The Turkish Dorcadiini with zoogeographical remarks (Coleoptera: Cerambycidae: Lamiinae). Munis Entomology \& Zoology, 5, 380-498.

Özdikmen, H. (2016). Dorcadionini of Turkey (Coleoptera: Cerambycidae). Journal of Natural History, 50, 37-38.

Pizzo, A., Mercurio, D., Palestrini, C., Roggero, A. \& Rolando, A. (2006). Male differentiation patterns in two polyphenic sister species of the genus Onthophagus Latreille, 1802 (Coleoptera: Scarabaeidae): a geometric morphometric approach. Journal of Zoological Systematics and Evolutionary Research, 44(1), 54-62.

Pretorius, E. \& Scholtz, C.H. (2001). Geometric morphometrics and the analysis of higher taxa: a case study based on the metendosternite of the Scarabaeoidea (Coleoptera). Biological Journal of the Linnean Society, 74(1), 35-50.

Rohlf, F.J. (1999). Shape statistics: Procrustes superimpositions and tangent spaces. Journal of Classification, 16, 197-223.

Rohlf, F.J. (2013). tpsDig, 2.17 (Web page: http://life.bio.sunysb.edu/morph) (11 May 2020).

Sukhodolskaya, R.A. \& Saveliev, A.A. (2017). Impact of environmental factors on the body shape variation and sexual shape dimorphism in Carabus granulatus L. (Coleoptera: Carabidae). Zoological Systematics, 42(1), 71-89.

Vesovic, N., Ivanovic, A. \& Curcic, S. (2019). Sexual size and shape dimorphism in two ground beetle taxa, Carabus (Procrustes) coriaceus cerisyi and C.(Morphocarabus) kollari praecellens (Coleoptera: Carabidae)-A geometric morphometric approach. Arthropod Structure Development, 49, 1-9.

Young, O.P. (2015). Size relationships, early reproductive status, and mandibular wear in adult Tetracha (=Megacephala) carolina (L.) (Coleoptera: Carabidae: Cicindelinae). The Coleopterists Bulletin, 69(1), 167-173.

Wainwright, P.C. (1994). Functional morphology as a tool in ecological research, In: Wainwright, P.C. \& Reilly, S.M. (Ed), Ecological morphology. Integrative organismal biology, 42-59p, University of Chicago Press, USA. 